\author{
Available online at http://bajas.edu.iq \\ https://doi.org/10.37077/25200860.2019.269 \\ College of Agriculture, University of Basrah
}

Basrah Journal of Agricultural Sciences

ISSN 1814 - 5868 Basrah J. Agric. Sci., 32 (Spec. Issue 2): 207-219, 2019

E-ISSN: 2520-0860

\title{
Biological Control of Charcoal Rot Disease Caused by Macrophomina phaseolina (Tassi) Goid on Cowpea and Mung Bean by Some Isolates of Streptomyces spp.
}

\author{
Mohammad A. Jaber * \&Mohammed A. Fayyadh \\ Department of Plant Protection, College of Agriculture, University of Basrah, Iraq \\ *Corresponding authore-mail: aa371186@gmail.com
}

Received 19 September 2019; Accepted 22 November 2019; Available online 22 November 2019

\begin{abstract}
Thirty-nine isolates of Actinomycetes were isolated from different sources such as rhizosphere and plant roots of Alfalfa, Clovers, cowpea, Mung bean, sorghum and date palms. Biochemical tests showed that all isolates were gram positive and capable of producing amylase, catalase and gelatinase enzymes. The isolates showed a positive test for gram staining. The isolates were capable of producing the enzymes of amylase, catalase and gelatinase. Dual culture technique showed that Streptomyces griseorubens, S. tendae 6, S. tendae $2, S$. tendae 5, S. parvulus and $S$. tendae 6 had high antagonistic activity against Macrophomina phaseolina as a zone of inhibition reached 15, 14, 13, 15, 14 and $12 \mathrm{~mm}$, respectively. Molecular identification revealed that actinomycetes isolate No 15, 23, 24 and 30 isolated from rhizosphere of Clovers, Sorghum, Alfalfa, Mung bean had 99\% similarity with S. tendae while Actinomycetes No 38 isolated from rhizosphere of Cowpea had 99\% similarity with S. grseorubens and isolate No 27 isolated from date palms had 99\% similarity with S.parvulus. all isolate were deposited at NCBI with GenBank accession number LC499602.1, LC499603.1, LC499606.1, LC499607.1, LC499604.1, LC499605.1. The isolate of S. griseorubens showed high efficacy in reducing disease. Which was $10.1 \%$ compared with $49.5 \%$ in control treatment on cowpea. $22.0 \%$ in mung bean compared to $43.4 \%$ in control treatment. In the field experiment, the results showed that soil treated with Actinomycetes isolates led to an increase in the percentage of seed germination and reduced the percentage of fungus infection. S. griseorubens reduced the percentage of infection to $11.54 \%$ compared to $32.33 \%$ in control treatment.
\end{abstract}

Keywords: Rhizosphere, S. griseorubens, S. tendae, S. parvulus

\section{Introduction}

Control of the charcoal rot disease caused by Macrophomina phaseolina a challenge to plant pathologist for several reason Such as the ability of the fungus to survive in form of sclerotia that stays alive in soil for 3-5 years, which make the crop rotation ineffective in control of charcoal disease. In addition to the broad host range, that may reach 500 plant species grown in large areas and makes chemical control economically useless.

Several strategies used against charcoal rot diseases, such as chemical control and solar pasteurization (Mahology, 1994). However, Biological control of plant pathogens has become a key component of disease management in light of the environment and health issues attributed to the use of 
fungicides in agriculture, biocontrol is mainly based on the use of organisms that possess several mechanisms such as parasitism, antagonism, competition as well as stimulate systemic resistance to the plant and improve absorption of nutrients (Stirling et al., 2017). Actinomycetes are among the essential organisms characterized by their ability to produce several active compounds against of plant pathogen such as Sideroophores, Kaempferol, isoscutellarin, umbelliferone and Cichoriin(Wan et al., 2008). The first step ofbiological control begins with organism that has ability to antagonist with plant pathogen organismsof plant pathogens in the local environment.Actinomycetes were used in the control of several pathogens such as: Streptomyces philanthi RM-1-138 in the control of Rhizoctonia solani solani, Pyricularia grisea, Bipolaris oryzae and Fusarium fujikuroi (Boukaew et al., 2013), Streptomyces and Micromonospora in the control Sclerotinia minor (El-Tarabily et al., 2008). Because of the importance of charcoal rot disease on cowpea and Mung bean to search for an alternative approach of chemical control, this study came out to evaluate the efficiency of isolates of Actinomycetes isolated from local sources in controlling the charcoal rot disease.

\section{Materials \&Methods}

\section{Isolation of the fungus $M$. phaseolina}

Several samples were collected from different agricultural area in Thi-Qar city the plant samples include cowpea, mung bean, cucumber, eggplant, okra and pepper, which showed symptoms of yellowing, wilting, and root rot. Fungal isolation was done according to Dhingra et al. (1978). The samples were stored on a PDA media in slants at $4^{\circ} \mathrm{C}$ for further use.

\section{Isolation of Actinomycetes}

\section{Isolated from soil}

Several soil samples were collected randomly from different agricultural areas that were planted with many agricultural crops such as cucumber, pepper. Several soil samples were collected randomly from different agricultural area, soil Samples were took from rhizosphere zone at $20 \mathrm{~cm}$ depth, isolation of Actinomycetes from soil samples were done by dilution plate, and ISP4 media were used (El-Tarabily et al., 2008), but isolation of Actinomycetesfom roots were made by placing three surface sterilized pieces in petri dishes containing ISP4 media, all plates were incubated at 30c for 4-10 days.

\section{Identification of Actinomycetes}

1- Biochemical test. Actinomycetes isolates identified according to the biochemical test such as gram staining. In addition to, amylase, gelatinase and catalase activity.

2-Molecular Identification of DNA extracted from six bacterial isolates from actinomycetes using Geneaid GSYNCTM DNA Extraction Kit GS100. The purity of the extracted DNA was measured using a Nanodrop device. Then PCR amplification was done by forward primer (CGCGGCCTATCAGCTTGTTG) and reverse primer (CCGTACTCCCCAGGCGGGG) tape by method (Igbinosaet al., 2017).

\section{Effect of Actinomycetes isolates against $M$. phaseolina}

Dual culture plate technique used to study the antagonistic activity of the Actinomycetes isolates against $M$. phaseolina. Mycelial disk $(0.5 \mathrm{~cm}$ in diameter), that have been taken from actively growing 4-day old culture of were transferred to the centre of Petri dishes $(9 \mathrm{~cm})$ containing sterilized PDA, after that 4 days of each isolate of A ctinomycetes 
placed $3 \mathrm{~m}$ from the disk of $M$. phaseolina. 4 disk were transferred from pure culture for each isolate of Actinomycetes bacteria. They placed $3 \mathrm{~cm}$ from the centre of each dish on the edges of two perpendicular diameters.control treatment, petri dishes were contained only $M$. phaseolina. Plates were incubated at the experiment were conducted in four replicate for each treatment. The percentage of the inhibition was calculated according to the following formula (Khamna et al., 2009).

$\mathrm{C}=\mathrm{A}-\mathrm{B}$

$\mathrm{C}=$ inhibition zone

$\mathrm{A}=$ the distance between the fungus disk and the bacterial $3 \mathrm{~cm}$.

$\mathrm{B}=$ fungus growth distance towards bacteria.

\section{Effect of Streptomyces isolates on Cowpea} and mung bean infection by $M$. phaseolina

Soil was mixed with peat moss at a ratio of 1 : 3 and then sterilized with a solution of $40 \%$ the formalin was diluted with water at ratio 1:50, and $3 \mathrm{~L}$ of solution was used for each $1 \mathrm{~m} 3$ and water at a ratio of 50: 1 The soil was placed in plastic bags and sealed well for 3 days. Then exposed to air and sunlight for 3 days for evaporation of formalin. Sterilized soil mixture was filled in plastic pots sized 22 x $22 \mathrm{~cm}$. The soil mixture was inoculated with $M$. phaseolina grown on millet seeds in the ratio of $5 \mathrm{~g}$ per pot(--kg soil), after two days the Streptomyces isolates grown in nutrient broth were added to pot soil in a ratio of $100 \mathrm{ml}_{\text {.pot }}{ }^{-1}$. The soil was irrigated and left for two days after that pots were planted with cowpea and mung bean seeds as 20 seeds per pot. The experiment was carried out with three replicate for each treatment Control treatment include cowpea or mung bean seeds planted in soil infested with $M$. phaseolina alone and planted with cowpea or mung bean seeds only. After21 days germination percentage, germination speed disease incidence and disease severity was measured.

\section{Germination speed(G.S)}

$$
=\frac{(\mathrm{A}) \mathrm{n} 1+(\mathrm{a}+\mathrm{b}) \mathrm{n} 2+(\mathrm{b}+\mathrm{c}) \mathrm{n} 3+(\mathrm{c}+\mathrm{d}) \mathrm{n} 4+\ldots \ldots \ldots}{\mathrm{a}+\mathrm{b}+\mathrm{c}+\mathrm{d} .}
$$

$\mathrm{a}, \mathrm{b}, \mathrm{c}, \mathrm{d}, \ldots \ldots . . . .$. represents the number of germinating seeds in each count

n 1, n 2, n 3, n 4 represents the time period between each count

$$
\text { Percentage of germination }=\frac{\text { Number of germinated seeds }}{\text { Total of seeds }} \times 100
$$

Disease incidence $\left(\right.$ D. I) $=\frac{\text { Number of infected plants }}{\text { Total of plants }} \times 100$

$$
\begin{aligned}
& \text { Disease severity (D.S) \% } \\
& =\frac{\text { Total number of plants of class } 0 \times 0+\text { Total number of plants of class } 4 \times 4 \mathrm{nts}}{\text { Total number of plants examined } \times \text { highest degree }} \times 100
\end{aligned}
$$




\section{Guide (0-4 degrees) for disease severity}

0 : The plant is healthy,

1: slight discolouration in the roots system and yellowing of a quarter of the shoot system.

2: Discolouration of brown discolouration of half root system with yellowing of half shoot system the root system brown and yellowing of half of the shoot system.

3: Discolouration of three-quarters of the root system and yellowing of the whole plant.

4: complete death of the plant with the observation of sclerotia in the area of infection. The severity of the infection was calculated according to the Mickinney (1923) equation.

\section{Statistical analysis}

Randomized Completely Blocks Design (RCBD) was used to analyze the results of laboratory and field experiments, and the least significant difference was used to compare the means. (SPSS) the program was used to analyze the results.

\section{Results \&Discussion}

\section{Isolation and Identification of $M$. phaseolina}

The fungus of $M$. Phaseolina was isolated from six plants. The isolates gave different symbols derived from the scientific name of the fungus and the English name of the host plant Table 1. All isolates were characterized by rapid growth in the PDA media as fungal mycelium started transparently and then turned to white and then to black grey. All isolates formed sclerotia varying in sizes and shapes. The isolates varied in the nature of their growth. The presence of arial mycelium characterized as in isolate of $\mathrm{MPhPe}$ and $\mathrm{MPhKu}$ isolated from pepper and mung bean respectively some isolate were characterized by white colony such as the isolate $\mathrm{MPhE}$ which isolated from eggplant. The fungus was identified according to Domsch et al. (1980).

\section{Isolation of Actinomycetes}

The Actinomycetes were isolated from the following sources. four isolates from each mung bean and cowpea roots, two from alfalfa roots, 7 from date palm roots and two from sorghum roots while 20 isolates were isolated from Rhizosphere of different plants. Isolation of Actinomycetes from plant roots was consistent with roots isolation and was consistent with Matsumoto \& Takahashi (2017), who indicated the possibility of isolating Actinomycetes of plant roots and the Rhizosphere area. The Actinomycetes can live in and around the roots of the plant where 40 isolates isolated from the surface and the roots of the Eucalyptus trees. (Himaman et al., 2016) isolated the Actinomycetes from the roots of the Eucalyptus trees. Gangwar et al. (2014) obtained 29 isolates of the Actinomycetes bacteria from Ocimum roots and were belong to the genus of Micromonospora, Actinopolyspora, Saccharopolyspora, and Streptomyces. Tokala et al. (2002) isolated the Actinomycetes bacteria from the roots of legume plants. Actinomycetes bacteria were isolated from the roots of the lemongrass plant (Khamna et al., 2010). In the previous study, Actinomycetes isolated from the rhizosphere and exhibited inhibition activity against several plant pathogenic fungi. Conducted by Dhanasekaran et al. (2012), he isolated Actinomycetes from the rhizosphere; moreover, the isolates showed the effectiveness of inhibition for several pathogenic fungi. 


\section{Identification of Actinomycetes bacteria}

Actinomycetes isolates appeared on the mediaof the ISP4 with a leathery and waxy appearance in the form of circular colonies with a black colour similar to a filamentshaped dot. After purification on the ISP4 media, the colonies formed a white and grey, and high filamentous growth from the surface of the media. Most of the isolates grew well and produced pigments in the media, including yellow, pink, and creamy. These characteristics did not appear in all media but on some of the media. These results agree with the observations of Nonoh (2013) that the Actinomycetes bacteria grow in a filamentous, and the high form in the media and characterized by the producing of pigments in the media. In shape and the colour of the colony, the results agree with Ramadan \& Alfeel (2013). Himaman et al. (2016) isolated of Actinomycetes bacteria from the roots, and the rhizosphere showed air mycelium of the isolates was white, pink, grey, yellow, and brown. The characteristic variation of Actinomycetes bacteria in growth on some media agrees with Kishore (2011).
Wan et al. (2008) showed that the colour of the air mycelium and the production of the pigment in the media have an essential role in bacteria identification. Moreover, the typical colours were white, grey, red, green, blue, purple, and other colours are not characteristic. Awad \& Fayyadh (2018) mentioned that the Actinomycetes were producing pigments such as yellow, brown, dark brown, and grey. when they study the effectiveness of the Actinomycetes against damping-off which caused by $R$. solani and Pythium spp. The results of Table 4 showed that all the isolates of Actinomycetes bacteria gave which exhibited antagonistic activity. These results were in agreement with Mansour et al. (2015), which showed that the isolates of Actinomycetes bacteria isolated from soils gave positive results in the test of enzymes amylase, catalase, gelatinase and oxidase and all were positive for gram stain. The results were in agreement with Ramadan \& Alfeel (2013) in the results of the biochemical tests carried out on the isolates of Actinomycetes bacteria isolated from soil,

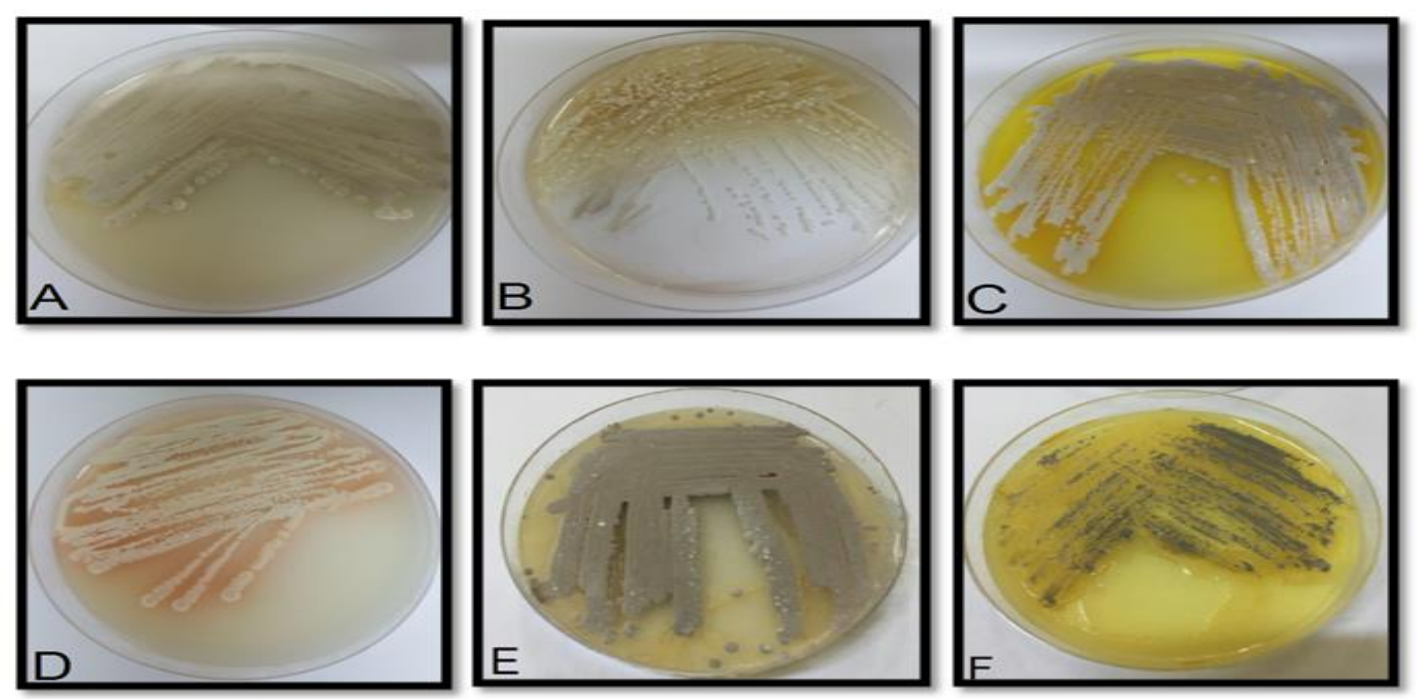

Fig. (1): Phynotypes of actinomycetes isolates on ISP4 media

$\mathrm{A}=$ S.tendae $5, \mathrm{~B}=$ S. tendae $1, \mathrm{C}=$ S.griseorubens, $\mathrm{D}=S$. parvulus, $\mathrm{E}=S$. tendae 2 , $\mathrm{F}=$ S. tendae 6 


\section{The molecular identification of}

\section{Actinomycetes}

The results of molecular identification of Actinomycetes isolates showed that the sequence of nitrogenous bases of the $16 \mathrm{~S}$ rRNA of isolate No isolated from clover roots were related to $S$. tendae with $100 \%$ similarity $100 \%$. Isolation number 2 isolated from the corn roots was related to $S$. tendae by $99.68 \%$ similarity, 1134, and 100\%correlation. Isolation 3 isolated from the bean roots was related to $S$. griseorubens by $100 \%$ similarity, 1013 , and $100 \%$ correlation isolates no 4 from the roots palm tree was related to Streptomyces parvulus by $99.43 \%$ similarity $99 \%$ correlation. Isolation 5 isolated from the roots of the Alfalfa was related to $S$. tendae with an identification of $99.84 \%$, 1147, and 99\%correlation. Isolation number 6 isolated from the roots of the mung bean matched to $S$. tendae by $100 \%$ identification, 1146, and 100\%correlation.PCR technology has been used in the identification of Actinomycetes bacteria in several studies. Chandrakar\& Gupta (2018) used PCR in the identification of $S$. parvulus isolated from the roots of the Aloe Vera plant. The results of isolation of Streptomyces griseorubens from soil were in agreement with a study conducted by Al-Askar et al. (2015) used the PCR technique to identify the bacteria. $S$. tendae isolated from soil was identified by Kavitha \&Vijayalakshmi (2011), which in the control of plant pathogen fungi. The isolates submitted on gene bank NCBI under independent accession numbers from LC499602 until LC499607.

Table (1): Molecular identification of Actinomycetes Isolates

\begin{tabular}{|c|c|c|c|c|c|c|}
\hline Source & $\begin{array}{l}\text { Definition in } \\
\text { NCBI }\end{array}$ & $\begin{array}{l}\text { accession } \\
\text { No. }\end{array}$ & $\begin{array}{l}\text { Congruenc } \\
\mathrm{e}\end{array}$ & $\begin{array}{l}\text { Total } \\
\text { Score }\end{array}$ & $\begin{array}{l}\text { Defini } \\
\text { tion } \\
\text { ratio }\end{array}$ & $\begin{array}{l}\text { Isolation } \\
\text { matching }\end{array}$ \\
\hline $\begin{array}{l}\text { Clovers } \\
\text { rhizosphere }\end{array}$ & S. tendaeMoh1 & $\begin{array}{l}\text { LC49960 } \\
2.1\end{array}$ & $100 \%$ & 1138 & $100 \%$ & $\begin{array}{l}\text { MN19949 } \\
9.1\end{array}$ \\
\hline $\begin{array}{l}\text { Sorghum } \\
\text { rhizosphere }\end{array}$ & S. tendaeMoh2 & $\begin{array}{l}\text { LC49960 } \\
3.1\end{array}$ & $100 \%$ & 1134 & $\begin{array}{l}99.68 \\
\%\end{array}$ & $\begin{array}{l}\text { MN19949 } \\
9.1\end{array}$ \\
\hline $\begin{array}{l}\text { Cowpea } \\
\text { rhizosphere }\end{array}$ & $\begin{array}{l}\text { S. } \\
\text { grseorubens Mo } \\
\text { h3 }\end{array}$ & $\begin{array}{l}\text { LC49960 } \\
4.1\end{array}$ & $100 \%$ & 1013 & $100 \%$ & $\begin{array}{l}\text { MG59760 } \\
1.1\end{array}$ \\
\hline $\begin{array}{l}\text { date palms } \\
\text { rhizosphere }\end{array}$ & $\begin{array}{l}\text { S. } \\
\text { parvulusMoh4 }\end{array}$ & $\begin{array}{l}\text { LC49960 } \\
5.1\end{array}$ & $99 \%$ & 1002 & $\begin{array}{l}98.43 \\
\%\end{array}$ & $\begin{array}{l}\text { MK39206 } \\
3.1\end{array}$ \\
\hline $\begin{array}{l}\text { Alfalfa } \\
\text { rhizosphere }\end{array}$ & S. tendaeMoh5 & $\begin{array}{l}\text { LC49960 } \\
6.1\end{array}$ & $99 \%$ & 1147 & $\begin{array}{l}99.84 \\
\%\end{array}$ & $\begin{array}{l}\text { MN19949 } \\
9.1\end{array}$ \\
\hline Mung bean roots & S. tendaeMoh6 & $\begin{array}{l}\text { LC49960 } \\
7.1\end{array}$ & $100 \%$ & 1146 & $100 \%$ & $\begin{array}{l}\text { MN19949 } \\
9.1\end{array}$ \\
\hline
\end{tabular}


Effect of Actinomycetes isolates against $M$. phaseolina

The results of table (2) and fig. (2) showed that all Actinomycetes isolates showed moderate inhibitory ability against the growth of $M$. phaseolina. Inhibition zoon ranged from 15-12 $\mathrm{mm}$ for all isolates. The same table showed that were statistical differences between isolates in the inhibitory ability. $S$. tendae 5 and $S$. griseorubens had the highest inhibition zoon of $15 \mathrm{~mm}$ compared with $S$. tendae 1 and isolate $S$. tendae 2 , which has an inhibition zoon of 13 and $12 \mathrm{~mm}$ respectively. These results were in agreement with Bubici (2018), that noted the role of Actinomycetes bacteria in inhibiting the growth of Fusarium spp. in vitro and reducing the Wilt disease by 55\%. (Goudjal et al., 2014).

Table (2): Antagonist's capability of some isolates of Streptomyces isolates against $M$. phaseolina in dual culture.

\begin{tabular}{lcc}
\hline Actinomycetes & Zone of Inhibition $(\mathrm{mm})$ & Inhibitory capability \\
\hline S. tendae6 & 14 & ++ \\
\hline S. tendae2 & 13 & ++ \\
\hline S.tendae5 & 15 & ++ \\
\hline S. parvulus & 14 & ++ \\
\hline S. tendae 1 & 12 & ++ \\
\hline S. griseorubens & 15 & ++ \\
\hline L.S.D. 0.01 & 0.53 & \\
\hline
\end{tabular}
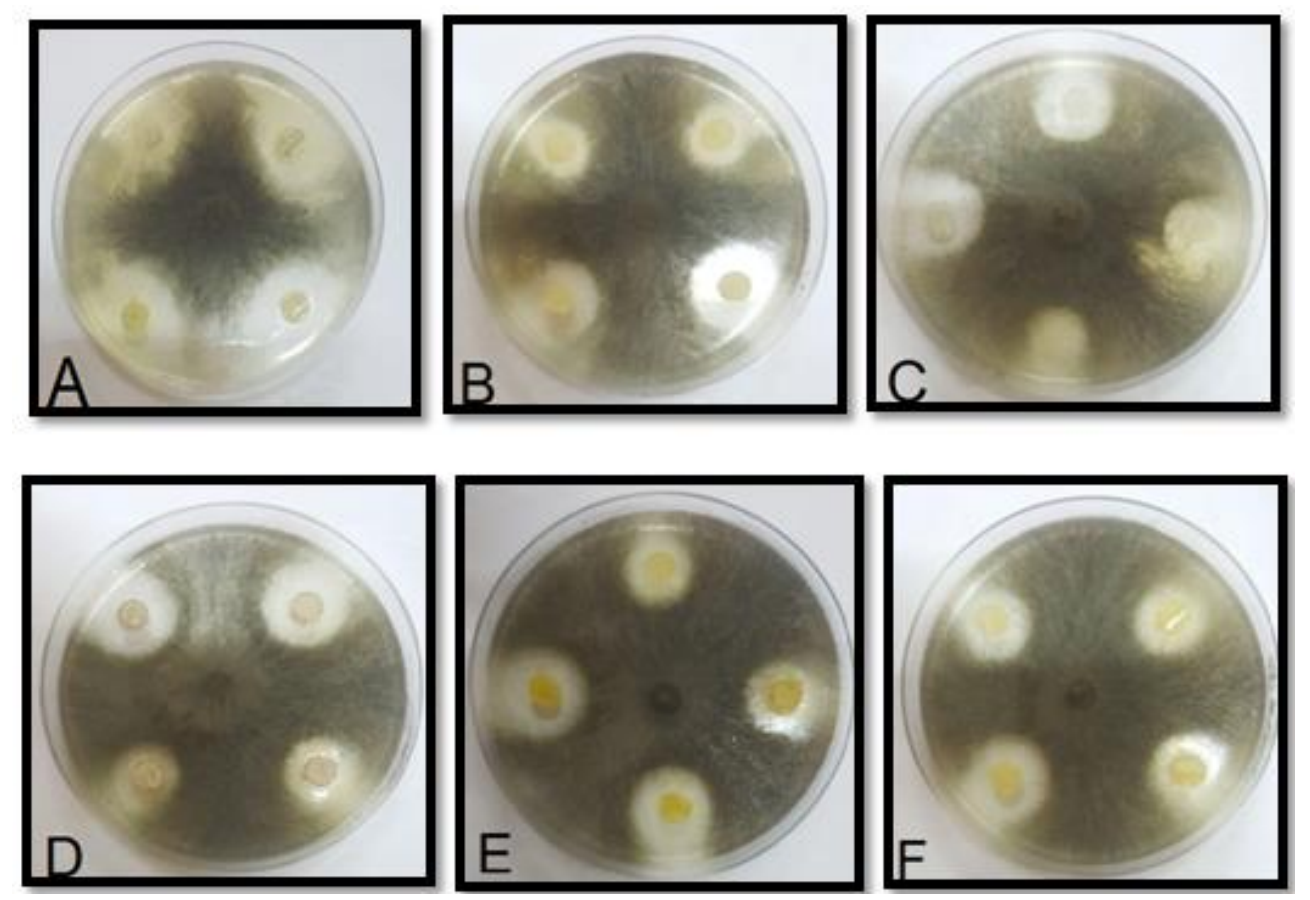

Fig. (2): Inhibition Actinomycetes against M. phaseolina.

$\mathrm{A}=S$. griseorubens, $\mathrm{B}=S$. tendae $5, \mathrm{C}=S$. tendae $2, \mathrm{D}=S$. tendae $6, \mathrm{E}=S$. parvulus $\mathbf{F}=$ S. tendae 1 . 
Previous study indicated that $S$. aureofaciens inhibit the growth of $M$. phaseolina and this ability attributed to the ability of this bacteria to produce siderophore compound (Shrivastava et al., 2017), indicated the capability of Streptomyces aureofaciens to inhibit the growth of $M$. phaseolina that attributed to the ability of this species of bacteria to produce a chelating compound of iron Siderophores. It documented that $80 \%$ of antibiotics are known to be obtained from Actinomycetes, mostly Streptomyces and Micromonospora $(\mathrm{H}$ assan et al., 2011). Bibb (2005) reported that inhibitory capability of actinomycetes bacteria against $M$. phaseolina is due to their production of secondary metabolites such as erythromycin and streptomycin that may be used in antagonists with other organisms.

\section{Effect of Streptomyces isolates on charcoal rot disease on cowpea and mung bean}

The results of (Table 3) showed that $M$. phaseolina significantly reduced the percentage of Cowpea and mung bean seeds germination which were 83.3 and $81.1 \%$, respectively, compared to the control treatment2, which were $95.52 \%$ and $91.0 \%$ for Cowpea and mung bean respectively. However, the addition of Actinomycetes isolates reduced the negative effect of $M$. phaseolina as the percentage of germination increased significantly compared with the control treatment1 (soil Cowpea and mung bean, respectively, with fungus). The highest percentage of germination recorded in the treatment of $S$. griseorubens and $S$. tendae 2 at 98.8 and $100 \%$ for Cowpea and mung bean, respectively. The results showed significant differences between the isolates of different bacteria, ranged from $85.5 \%$ to $98.8 \%$ for Cowpea and 87.7 to $100 \%$ for mung bean. The results of this experiment were an agreement with several previous studies. Goudjal et al. (2014) and Bubici, (2018) indicated that Actinomycetes possess the ability to reduce the negative effect of several plant pathogenic fungi and increase plant growth parameters. The increasing of seed germination speed may be due to the ability of Actinomycetes bacteria to produce growth regulators such as IAA, which has a significant role in increasing cell division speed and differentiation (El-Tarabily et al., 2008). Actinomycetes bacteria produce some acids, such as Pteridic acids, which have a similar role to that of IAA in promoting root formation and speed germination (Igarashi, 2004). The results showed that the highest percentage of infection on the bean was recorded in $M$. phaseolina treatment, which was $49.5 \%$ compared to $10.1 \%$ in $S$. griseorubens treatment. The highest infection percentage was recorded in the treatment of $S$. tendae 2 isolate, which reached $44.7 \%$.

The result may be inconsistent with the germination percentage in which this isolate recorded a high percentage of germination may be due to severable due to several reasons: S. tendae 2 encourages plant growth, stimulates seed germination and seedling growth. Actinomycetes bacteria have not a direct effect on the pathogen fungus; especially it is known the infection with $M$. phaseolina it may occur early in the age of the plant, but the symptoms do not appear only at the time of flowering or the beginning of the formation of fruit parts (Short et al., 1978).

The addition of actinomycetes isolates reduced the effect of the Disease severity $M$. phaseolina on mung bean, the percentage of infection in $S$. griseorubens decreased to $22.0 \%$, and the highest percentage of infection in $S$. parvulus was $42.2 \%$. The 
infection in other isolates ranged from 25.6 $39.9 \%$. The difference in the percentages of infection between the treatments may be due to differences in species of Actinomycetes bacteria or the difference in the nature of the materials and compounds produced from the bacteria (Dhansekaran, et al., 2012). The infection of the charcoal rot disease, the highest percentage of the severity of the infection, was recorded in the control treatment (1) which reached $39.33 \%$ on
Cowpea (Fig. 3) and $43.4 \%$ on mung bean. However, the adding of Actinomycetes isolates was significantly reduced the severity of the disease. The lowest percentage of severity in S. griseorubens was $9.2 \%$, and the percentage of disease severity in the other treatments ranged between $9.2-16.63 \%$ in cowpea and $10.3-17.33 \%$ in mung bean, and find significant differences with control treatment.

Table (3): Effect of some Actinomycetes isolates on germination and the infection severity of charcoal rot disease on bean and mung bean in pots experiment.

\begin{tabular}{lcccccc}
\hline Treatments & \multicolumn{3}{c}{ Mung bean } & \multicolumn{3}{c}{ cowpea } \\
\cline { 2 - 7 } & \%incidence & $\begin{array}{c}\% \\
\text { Disease } \\
\text { severity }\end{array}$ & $\begin{array}{c}\text { Germination } \\
\text { percentage }\end{array}$ & \%incidence & $\begin{array}{c}\% \\
\text { Disease } \\
\text { severity }\end{array}$ & $\begin{array}{c}\text { Germination } \\
\text { percentage }\end{array}$ \\
\hline S. tendae 6 & 12.0 & 31.2 & 92.22 & 21.26 & 32.3 & 86.16 \\
\hline S. tendae 2 & 17.33 & 29.0 & 100 & 15.66 & 44.7 & 93.33 \\
\hline S.tendae 5 & 14.4 & 25.6 & 96.75 & 11.32 & 19.3 & 86.66 \\
\hline S. parvulus & 15.5 & 42.2 & 88.85 & 16.63 & 27.2 & 97.77 \\
\hline S. tendae1 & 18.0 & 39.9 & 87.77 & 12.6 & 22.9 & 85.54 \\
\hline S. griseorubens & 10.3 & 22.0 & 93.3 & 9.2 & 10.1 & 98.8 \\
\hline $\begin{array}{l}\text { Control/ } \\
\text { Pathogen }\end{array}$ & 43.4 & 52.6 & 81.75 & 39.33 & 49.5 & 83.33 \\
\hline Control & 0.0 & 0.0 & 91.00 & 0.0 & 0.0 & 95.52 \\
\hline L.S.D. 0.05 & 0.67 & 2.10 & 1.08 & 1.28 & 3.6 & 1.02 \\
\hline
\end{tabular}
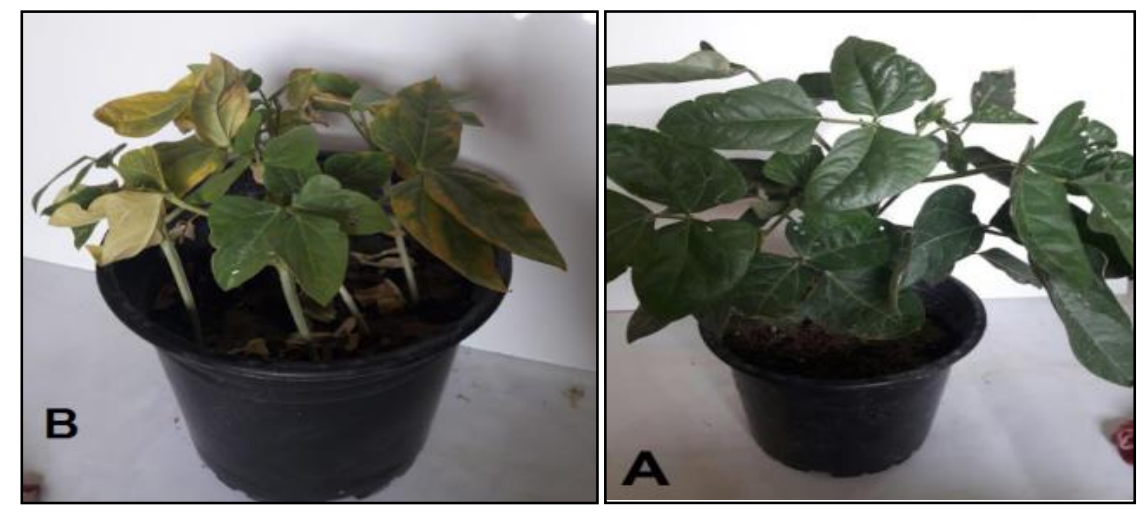

Fig. (3): Effect of Streptomyces isolates on charcoal rot disease on cowpea

$A=$ cowpea plant treated with Actinomycetes bacteria and the pathogen fungus. $B=$ cowpea plant treated with pathogenic fungus only. 
The results of this experiment were an agreement with several studies indicated that the use of Actinomycetes bacteria in reducing the severity of plant pathogens such as the using of Streptomyces spp. in the resistance of root rot caused by Rhizoctonia solani in tomato plant (Goudjal et al., 2014). Streptomyces spp. were used to resistance wilt diseases caused by Fusarium sp. (Bubici, 2018).

\section{Effect of Streptomyces isolates on charcoal rot disease on cowpea and mung bean}

The results of table (4) showed that the highest percentage of infection was recorded in the control treatment on Cowpea (soil contaminated with fungus), which was $31.38 \%$. The increasing of Actinomycetes isolates to soil reduced the effect of pathogenic fungi and significantly by control treatment (soil contaminated with fungus) as the percentage of infection decreased to $11.54 \%$ in the treatment of S. griseorubens. The highest infection percentage was recorded in the treatment of $S$. tendae 2 bacteria, which reached $20.32 \%$, but the other treatments ranged between 14.53 and $18.29 \%$. On the mung bean, the highest infection percentage was recorded in the treatment (soil contaminated with fungus) was $39.23 \%$. The adding of Actinomycetes isolates reduced the effect of the pathogenic fungi on the yield of mung bean with significant differences. The highest percentage of infection was $16.42 \%$ in $S$. tendae 1 treatment. The reason of difference in the percentages of infection between treatments due to the difference in the quantity and quality of the compounds produced from the filamentous bacteria. The percentage of the severity of infection was the highest in control treatment (soil contaminated with fungus) on Cowpea and mung bean, which was 29.11 and $32.54 \%$. The increasing of Actinomycetes isolates in the soil reduced the percentage of infection severity as the lowest infection severity in $S$. griseorubens was $8.12 \%$ and $10.34 \%$ in $S$. tendae 1 mung bean. The percentage of the severity of infection in other treatments ranged from 14.53 to $18.29 \%$ on cowpea and 11.87 to $17.34 \%$ on mung bean.

Table (4): Effect of some actinomycetes isolates on the infection and severity of charcoal rot on cowpea and mung bean plants (field experiment).

\begin{tabular}{ccccc}
\hline Treatments & Mung bean & \multicolumn{3}{c}{ cowpea } \\
\cline { 2 - 5 } & \%incidence & \% Disease severity & \%incidence & \% Disease severity \\
\hline S. tendae 6 & 10.34 & 13.32 & 10.56 & 17.64 \\
\hline S. tendae 2 & 15.89 & 12.34 & 12.26 & 20.32 \\
\hline S.tendae 5 & 12.12 & 11.26 & 11.43 & 14.53 \\
\hline S. parvulus & 17.34 & 14.29 & 10.23 & 18.29 \\
\hline S. tendae1 & 11.87 & 16.42 & 13.02 & 15.76 \\
\hline S. griseorubens & 12.69 & 13.45 & 8.12 & 11.54 \\
\hline Control/ pathogen & 32.54 & 39.23 & 29.11 & 31.38 \\
\hline L.S.D. 0.05 & 1.31 & 0.09 & 0.20 & 0.53 \\
\hline
\end{tabular}



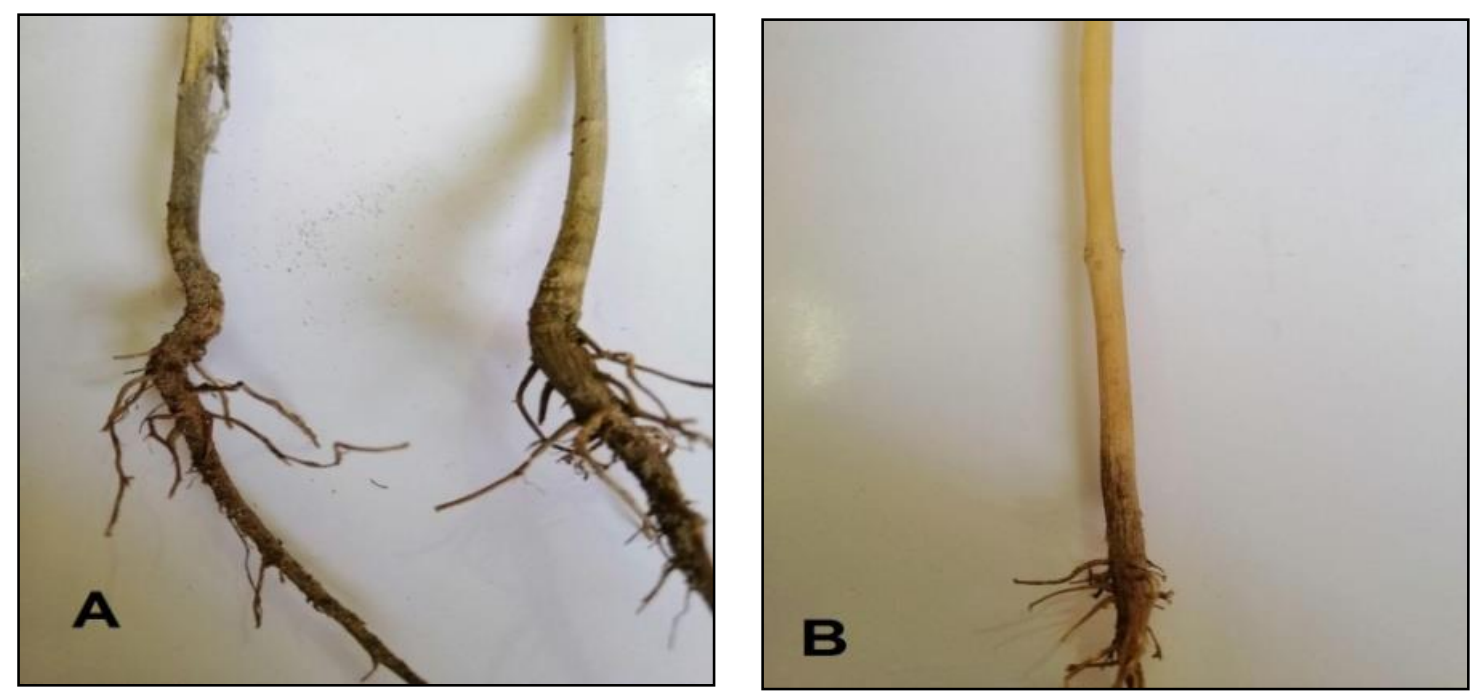

Fig. (4): The difference between infected and non-infected by charcoal rot.

$A=$ The shape of bean roots treated with pathogenic fungus only.

\section{B = shape of roots treated with pathogenic fungus and Actinomycetes bacteria.}

The results were an agreement with previous studies. Bubici (2018) referred to the role of Actinomycetes bacteria in controlling plant pathogenic fungi and reducing infection percentage and severity through the production of antibiotics and enzymes that affect the growth of fungi. El -Tarabily et al. (2000) indicated that Actinomycetes bacteria colonized plant roots and produce enzymes such as catalase, b-1, 3-glucanase, and antibiotics that decay the fungal cell walls.

\section{Conclusions}

This study showed the Possibility of isolating the Actinomycetes bacteria from the roots and the Rhizosphere area of different plants, and the ability of Actinomycetes bacteria to reduce the infection of charcoal rot on cowpea and mung bean, and have a role in promoting plant growth.

\section{Acknowledgments}

We would like to thank Labeed A. Al-Saad, Department of Plant Protection, College of Agriculture, University of Basrah, for conducting molecular identification and Prof. Dr. Asaad Y. Ayied, Department of Animal
Production, for helping us with the statistical analysis.

\section{References}

Al-Askar, A.A.; Rashad, Y.M.; Hafez, E.E.; Abdulkhair, W.M.; Baka, Z.A. \& Ghoneem, K.M. (2015). Characterization of alkaline protease produced by Streptomyces griseorubens E44G and its possibility for controlling Rhizoctonia root rot disease of corn. Biotechnol. Biotechnol. Equipment. 29(3): 457-462.

Awad, L.K. \& Fayyadh, M.A. (2018). The activity of some Actinomycetes isolates in control of cucumber damping off disease caused by Rhizoctiona solani and Pythium sp. Basrah J. Agric. Sci., 31(2): 11-23.

Bibb, M.J. (2005). Regulation of secondary metabolism in Streptomycetes. Curr. Opin. Microbiol. 8(2): 208-215.

Boukaew, S.; Plubrukam, A. \& Prasertsan, P. (2013). Effect of volatile substances from Streptomyces philanthi RM-1-138 on growth of Rhizoctonia solanion rice leaf. BioControl, 58(4): 471-482. 
Bubici, G. (2018). Streptomyces spp. as biocontrol agents against Fusarium species. Rev., 13(50): 1-15.

Chandrakar, S. \& Gupta, A.K. (2018). Actinomycin-producing endophytic Streptomyces parvulus associated with root of Aloe vera and optimization of conditions for antibiotic production. Probiotics Antimicrob. Proteins, 11(3): 1055-1069.

Dhanasekaran, D.; Thajuddin, N. \& Panneerselvam, A. (2012). Applications of actinobacterial fungicides in agriculture and medicine. 29-54. In Dhanasekaran, D. (Ed.). Fungicides for Plant and Animal Diseases. Intech. Croatia: 298pp.

Dhingra, O.D. \& Sinclair, J.B. (1978). Biology and pathology of Macrophomina phaseolina Imprensa Universitaria. Universidade Federal de Vicosa. Vicosa, Minas Gerais, Brazil. 166pp.

Domsch, K.H.; Gams, W. \& Anderson, T.H. (1980). Compendium of Soil Fungi: A Subsidiary of Harcourt Brace. Vol. 1. Jovanovich Publ. Acad. Press: 860pp.

El-Tarabily, K.A.; Nassar, A.H. \& Sivasithamparam, K. (2008). Promotion of growth of bean (Phaseolus vulgaris L.) in a calcareous soil by a phosphatesolubilizing, rhizosphere-competent isolate of Micromonospora endolithica. Appl. Soil Ecol., 39(2): 161-171.

El-Tarabily, K.A.; Soliman, M.H.;Nassar, A.H.; Al-Hassani, H.A.; Sivasithamparam, K.; McKenna, F. \& Hardy, G.S.J. (2000). Biological control of Sclerotinia minor using a chitinolytic bacterium and Actinomycetes. Plant Pathol., 49(5): 573583.
Gangwar, M.; Dogra, S.; Gupta, U.P. \& Kharwar, R.N. (2014). Diversity and biopotential of endophytic actinomycetes from three medicinal plants in India. Afr. J. Microbiol. Res., 8(2): 184-191.

Goudjal, Y; Toumatia, O.; Yekkour, A.; Sabaou, N.; Mathieu, F. \& Zitouni, A. (2014). Biocontrol of Rhizoctonia solani damping-off and promotion of tomato plant growth by endophytic actinomycetes isolated from native plants of Algerian Sahara. Microbiol. Res., 169(1): 59-65.

Hassan, A.A.; El-Barawy, A.M. \& El Mokhtar, M.N. (2011). Evaluation of biological compounds of Streptomyces species for control of some fungal diseases. J. Am. Sci., 7(4): 752-60.

Himaman, W.; Thamchaipenet, A.; Pathomaree, W. \& Duangmal, K. (2016). Actinomycetes from Eucalyptus and their biological activities for controlling Eucalyptus leaf and shoot blight. Microbiol. Res., 188:42-52.

Igarashi, Y. (2004). Screening of novel bioactive compounds from plantassociated actinomycetes. Actinomycetologica, 18(2): 63-66.

Kavitha, A. \& Vijayalakshmi, M. (2011). Partial purification and antifungal profile of chitinase produced by Streptomyces tendae TK-VL, 333. Ann. Microbiol., 61(3): 597-603.

Khamna, S.; Yokota, A. \& Lumyong, S. (2009). Actinomycetes isolated from medicinal plant rhizosphere soils: diversity and screening of antifungal compounds, indole-3-acetic acid and siderophore production. World J. Microbiol. Biotechnol., 25(4): 649-655.

Khamna, S.; Yokota, A.; Peberdy, J.F. \& Lumyong, S. (2010). Indole-3-acetic acid 
production by Streptomyces sp. isolated from some Thai medicinal plant rhizosphere soils. Eur. Asian J. BioSci., 4: 23-32.

Kishore, P. (2011). Isolation, characterization and identification of Actinobacteria of Mangrove ecosystem, Bhitarkanika, Odisha. Ph. D. Thesis. National Institute of Technology Rourkela: 85pp.

Mahology, M.V. (1994). Longevity of Macrophomina phaseolinain different vegetable crops. Indian J. Mycol. Plant Pathol., 24: 164-166.

Mansour, S.R.; Abdel-Azeem, A.M. \& AboDeraz, S.S.S. (2015). A new record of action bacteria isolated from soil in Jerusalem and their enzymatic. F1000Research, 4(11): 1-10. DOI: 10.12688/f1000research.3257.1.

Matsumoto, A. \& Takahashi, Y. (2017). Endophytic actinomycetes: promising source of novel bioactive compounds. J. Antibiot., 70(5): 514-519.

Mickenny, H.M. (1923). Influence of soil temperature and moisture on infection of wheat seedling by Helmintho sporium sativum. J. Agric. Res., 26: 195 -217.

Nonoh, J.O. (2013). Isolation and characterization of actinobacteria with potential for control of Fusarium spp. and Colletotrichum kahawae M. Sc. Thesis, Jomo Kenyatta Univ. Agric. Technol.: 80pp.
Ramadan, N.A. \& Alfeel, F.K. (2013). Isolation soli of soli Actinomycetes producing antibiotic for pathogenic plant fungi. Mesopotamia J. Agric., 41(4): 295286.

Short, G.E. \& Wyllie, T.D. (1978). Inoculum potential of Macrophomina phaseolina. Phytopathology, 68: 742-746.

Shrivastava, P.; Kumar, R. \& Yandigeri, M.S. (2017). In vitro biocontrol activity of halotolerant Streptomyces aureofaciens K20: A potent antagonist against Macrophomina phaseolina (Tassi) Goid. Saudi J. Biol. Sic., 24(1): 192-199.

Stirling, F.;Bitzan, L.; O’Keefe, S.; Redfield, E.; Oliver, J.W.; Way, J.\& Silver, P.A. (2017). Rational design of evolutionarily stable microbial kill switches. Mol. Cell, 68(4): 686-697.

Tokala, R.K.; Strap, J.L.; Jung, C.M.; Crawford, D.L.; Salove, M.H.; Deobald, L.A. \& Morra, M.J. (2002). Novel plantmicrobe rhizosphere interaction involving Streptomyces lydicus WYEC108 and the pea plant (Pisum sativum). Appl. Environ. Microbiol., 68(5): 2161-2171.

Wan, M.; Li, G.; Zhang, J.; Jiang, D. \& Huang, H.C. (2008). Effect of volatile substances of Streptomyces platensis F-1 on control of plant fungal diseases. Biol. Control, 46(3): 552-559. 